\title{
ROZMOWY SZEŚCIOSTRONNE - DYPLOMATYCZNE WYZWANIE WOBEC PROBLEMU DENUKLEARYZACJI PÓŁWYSPU KOREAŃSKIEGO ${ }^{1}$
}

Historia północnokoreańskich ambicji militarnych zaczęła się wraz z powstaniem w 1948 r. Koreańskiej Republiki Ludowo-Demokratycznej. Posiadanie technologii nuklearnej stało się wręcz wyzwaniem komunistycznych władz. Uważano, że posiadanie broni nuklearnej będzie ważnym czynnikiem konsolidującym nowo powstały reżim i zapewni przewagę Korei Północnej na Półwyspie Koreańskim. Celem niniejszego artykułu jest ukazanie inicjatyw dyplomatycznych państw zainteresowanych denuklearyzacją Korei Północnej oraz udzielenie odpowiedzi na pytanie o skuteczność tych międzynarodowych zabiegów.

W latach sześćdziesiątych XX wieku broń atomowa była już w posiadaniu kilku państw: Stanów Zjednoczonych (pierwszy test nuklearny w 1945 r.), Związku Sowieckiego (1949 r.), Wielkiej Brytanii (1952 r.), Francji (1960 r.) czy Chińskiej Republiki Ludowej (1964 r.). Z inicjatywy Kim Ir Sena utworzono w 1962 r. Instytut Energii Atomowej, a dwa lata później, w 1964 r. powstał pierwszy północnokoreański ośrodek badań nuklearnych w Yŏngbyŏn (Heo, 2006). Była to odpowiedź władz w Pjongjangu na umieszczanie przez USA od 1958 r. głowic nuklearnych na terytorium Korei Południowej. W 1965 r. północnokoreańskie badania nad technologią jądrową rozwijały się w oparciu o otrzymany od Związku Sowieckiego reaktor badawczy służący do produkcji izotopów promieniotwórczych (Wit, Ponneman, Gallucci, 2004: 2-3). Uruchomiony po dwóch latach reaktor wykorzystywano w przemyśle, medycynie i badaniach naukowych. Ponadto Korea Północna nabyła również od Sowietów stos krytyczny o mocy 0,1 MW. Obydwa urządzenia po zainstalowaniu zostały objęte nadzorem ze strony inspektorów Międzynarodowej Agencji Energii Atomowej (Bayer, Dziak, 2006: 178).

$\mathrm{Na}$ początku lat 70. XX w. reżim północnokoreański zintensyfikował współpracę wojskową z Chińską Republiką Ludową. W ramach zawartych porozumień ChRL udostępniła m.in. technologie militarne, technologie systemów rakietowych, prowadzono wspólne prace naukowo-badawcze, a także kursy szkoleniowe dla kadry północnokoreańskiej w Chinach (Oberdorfer, 2001: 252-253). Co ciekawe, mimo że północnokoreański program budowy broni atomowej możliwy był głównie dzięki doświadczeniom i wsparciu ze strony Związku Sowieckiego i ChRL, to według propagandy Korei Północnej jest on sukcesem rodzimych badań technologicznych. W ostatniej dekadzie

Artykuł przygotowany na II Kongres Politologii, Polska i Europa wobec wyzwań wspótczesnego świata, Poznań, 19-21 września 2012 r. 
lat 70. XX w. na polecenie Kim Ir Sena północnokoreańska Akademia Nauk, Koreańska Armia Ludowa i Ministerstwo Bezpieczeństwa Publicznego podjęły działania mające na celu realizację programu budowy broni atomowej ze szczególnym uwzględnieniem prac w zakresie rozwoju technologii nuklearnych i rozbudowy instalacji jądrowych w ośrodku w Yŏngbyŏn (ibidem: 253).

Pomimo prowadzonych badań nad bronią nuklearna, w 1985 r. Korea Północna została sygnatariuszem Układu o nieproliferacji broni jadrowej (ang. Nuclear Non-Proliferation Treaty). W wyniku podpisania tego porozumienia Stany Zjednoczone zadeklarowały wycofanie z terytorium Korei Południowej swojej broni atomowej, co nastapiło po decyzji amerykańskiego prezydenta George'a H. W. Busha pod koniec $1991 \mathrm{r}$. W tym samym roku między państwami koreańskimi podpisano również dwie ważne umowy: 1) Zasadniczy uktad o pojednaniu, nieagresji oraz wymianie i wspótpracy (ang. Basic Agrement on Reconciliation, Non-aggression, Exchange and Cooperation) i 2) Wspólnq deklarację o denuklearyzacji Pólwyspu Koreańskiego (ang. Joint Declaration on Denuclearization of the Korean Peninsula) (Haliżak, 2004: 37-38). Układ o pojednaniu, nieagresji oraz wymianie i wspótpracy pomiędzy Potudniem a Pótnocq uznawany jest za jeden $\mathrm{z}$ najważniejszych dokumentów w historii stosunków międzykoreańskich (Levin, Han, 2002: 9).

W styczniu 1992 r. Korea Północna podpisała także porozumienie z Międzynarodowa Agencja Energii Atomowej w sprawie gwarancji bezpieczeństwa². Miesiąc później $\mathrm{w}$ tym samym roku odbyło się w Pjongjangu spotkanie pomiędzy premierami koreańskich rządów. Przedmiotem rozmów międzykoreańskich było między innymi porozumienie dotyczące pojednania, wezwanie do nieagresji, wymiana i współpraca, wspólna deklaracja dotycząca rozbrojenia jądrowego Półwyspu Koreańskiego oraz porozumienie w sprawie utworzenia Komisji ds. dialogu Północ-Południe.

Pomimo składanych deklaracji o braku zainteresowania produkcją broni atomowej, w 1993 r. doszło do pierwszego kryzysu nuklearnego wywołanego oskarżeniami pod adresem Korei Północnej o nieprzestrzeganie postanowień podpisanych wcześniej traktatów międzynarodowych. Rząd północnokoreański wydał oświadczenie, iż zamierza wystapić z układu o nieproliferacji broni jądrowej (Cha, 2012: 7). Oznaczało to, iż wspólna deklaracja podpisana przez szefów obu państw koreańskich, zawierająca klauzulę o zakazie produkcji broni jądrowej oraz przeprowadzenia prób i jej magazynowania, nie powstrzymała północnokoreańskich ambicji nuklearnych. Sytuacja stała się jeszcze bardziej napięta, gdy Korea Północna nie zezwoliła inspektorom Międzynarodowej Agencji Energii Atomowej na przeprowadzenie kontroli w obiektach badań nuklearnych (Oberdorfer, 2001: 254-255).

2 Układ o nierozprzestrzenianiu broni jądrowej, który wszedł w życie w 1970 r., jak też Międzynarodowa Agencja Energii Atomowej (International Atomic Energy gency, IAEA) z siedzibą w Wiedniu, miały swoje źródło w inicjatywach amerykańskiego prezydenta Dwight'a D. Eisenhowera. Zadaniem agencji, która powstała w 1957 r., było z jednej strony wspieranie rozwoju techniki jądrowej do celów wytwarzania energii elektrycznej i rozpowszechnianie jej na świecie, z drugiej zaś uniemożliwianie pracy nad bombą atomową, coraz większej liczbie państw. Więcej na ten temat: D. Fischer, History of the International Atomic Energy Agency, Division of Publications International Atomic Energy Agency, Vienna 1997, s. 9-15. 
W marcu 1993 r. komunistyczny rząd Korei Północnej wydał oświadczenie, iż zamierza wystapić z Układu o nieproliferacji broni jądrowej (Haliżak, 2004: 41), a w czerwcu 1994 r. podjął decyzje o rezygnacji z członkostwa w Międzynarodowej Agencji Energii Atomowej. Taka postawa władz w Pjongjangu sprawiła, że problem północnokoreańskiej broni jądrowej wywołał wielkie napięcie, nie tylko w regionie Azji Północno-Wschodniej, ale i na całym świecie. W rozwiązanie narastającego kryzysu wokół północnokoreańskiego problemu nuklearnego zaangażowała się Rada Bezpieczeństwa ONZ. Działania oenzetowskiej dyplomacji spowodowały, że władze Korei Północnej wstrzymały tymczasowo decyzję w sprawie wyjścia z Układu o nieproliferacji broni jadrowej.

W październiku 1994 r. w wyniku mediacji byłego prezydenta Stanów Zjednoczonych Jimmy'ego Cartera zostało podpisane w Genewie amerykańsko-północnokoreańskiego porozumienie w kwestii nuklearnej tzw. Porozumienie ramowe (ang. Framework Agrement) (Buzo, 1999: 204). Na mocy tej umowy Korea Północna zobowiązała się do pozostania w Układzie o nierozprzestrzenianiu broni jadrowej, zaprzestania wzbogacania plutonu, poddania swoich obiektów jądrowych kontroli międzynarodowych inspektorów oraz rezygnacji z badań atomowych i zakończenia działalności nuklearnej. Porozumienie pomiędzy Stanami Zjednoczonymi a Koreą Północną w sprawie nuklearnej złagodziło napięcie oraz zapewniło utrzymanie stanu bezpieczeństwa i pokoju na Półwyspie Koreańskim (Buzo, 1999: 351-357). Ponadto władze Korei Północnej zadeklarowały również likwidację instalacji nuklearnych, bowiem Stany Zjednoczone zgodzily się na utworzenie międzynarodowego konsorcjum w celu wybudowania w Korei Północnej dwóch reaktorów na lekką wodę. W skład utworzonej w 1995 r. Organizacji Rozwoju Energetycznego Pólwyspu Koreańskiego (ang. Korean Peninsula Energy Development Organization - KEDO) weszły: Stany Zjednoczone, Japonia i Korea Południowa. Zadaniem KEDO było zebranie środków finansowych potrzebnych na wybudowanie północnokoreańskiego reaktora energetycznego na lekką wodę oraz dostarczanie paliwa do Korei Północnej.

Pomimo północnokoreańskich deklaracji i zobowiązań o zaprzestaniu budowy reaktora grafitowego wywiad amerykański posiadał informacje na temat prowadzonych tajnych badań nad bronią masowego rażenia, w tym bronią chemiczną i biologiczną ${ }^{3}$. Przeprowadzenie próby rakietowej w sierpniu 1998 r., dokonanej za pomocą pocisku balistycznego Taepodong-1, który przeleciał nad terytorium Japonii potwierdziło wcześniejsze podejrzenia. Spowodowało to wstrzymanie przez Stany Zjednoczone dotacji na paliwa do Korei Północnej oraz zaprzestanie udzielania pomocy żywnościowej przez Japonię.

W 2002 r. doszło do drugiego kryzysu nuklearnego. Administracja George'a W. Busha zaliczyła do „osi zła” obok Iranu i Iraku, Koreę Północną uznając, że zagraża

3 Korea Północna posiada broń biologiczną, w tym bakterie: Clostridium botulinum, Yersinia pestis, Vibrio cholerae, Bacillus anthracis. W warunkach awaryjnych, może być zdolna do wytwarzania do 20000 ton środków chemicznych rocznie. Według tej prognozy, przemysł jest w stanie produkować szeroką gamę środków chemicznych, w tym: adamsyt (DM), chloroacetofenon (CN), chlorobenzylidene malononitrylu (CS), cyjanowodór (AC), fosgen (CG i CX), sarin (GB), Soman (GD), Tabun (GA). 
międzynarodowemu bezpieczeństwu (Fisher, 2006: 71; Flint, 2011: 59). Ponadto podczas październikowej wizyty w Pjongjangu Jamesa Kelly'ego zastępcy sekretarza stanu USA ds. Azji i Pacyfiku, władze północnokoreańskie oficjalnie przyznały się do prowadzenia tajnego programu nuklearnego (Wystannik USA w Korei Pótnocnej, $2002)^{4}$. Oświadczenie to było dowodem na naruszenie umowy o zamrożeniu programu jądrowego zawartej między Stanami Zjednoczonymi a Koreą Północną.

W październiku 2002 r. Stany Zjednoczone oskarżyły Koreę Północną o rozwijanie tajnego programu wytwarzania wysoko wzbogaconego uranu, będącego drugim, obok plutonu materiałem pozwalającym na wytworzenie broni jądrowej. W odpowiedzi na oskarżenia władze północnokoreańskie zdecydowały się na zerwanie plomb i usunięcie zainstalowanych przez inspektorów Międzynarodowej Agencji Energii Atomowej urządzeń monitorujących w ośrodku jądrowym w Yŏngbyŏn, po czym inspektorzy zobowiązani zostali do natychmiastowego opuszczenia Korei Północnej (Perry, 2006: 83-84).

W takich okolicznościach Stany Zjednoczone postawiły wówczas warunek udzielania dalszej pomocy żywnościowej i humanitarnej jedynie po zaprzestaniu prowadzenia programu atomowego. Reakcją na decyzję Waszyngtonu było ponowne uruchomienie zamrożonego w 1994 r. reaktora w ośrodku Yŏngbyŏn. Ponadto komunistyczne władze ogłosiły w styczniu 2003 r. wystąpienie z Układu o nieproliferacji broni jadrowej. Zerwały również grudniową Wspólnq deklarację o denuklearyzacji Półwyspu Koreańskiego podpisaną z Koreą Południową w $1991 \mathrm{r}$. W tym samym roku z inicjatywy zarządu Międzynarodowej Agencji Energii Atomowej północnokoreański problem nuklearny został przedstawiony na forum Rady Bezpieczeństwa ONZ.

Odpowiedzią na kolejny kryzys nuklearny oddalający groźbę północnokoreańskiego szantażu były podjęte w kwietniu 2003 r. w Pekinie rozmowy trójstronne, w których uczestniczyły: ChRL (w roli mediatora), Stany Zjednoczone oraz Korea Północna. W sierpniu tego samego roku do rozmów przystapiły także Rosja, Japonia i Korea Południowa, tworząc tak zwane negocjacje sześciostronne (ang. The Six-Party Talks) (Cha, Kang, 2003: 128; Twomey, 2008: 417-418). Podczas odbywających się rozmów, przewodniczący Hu Jintao podkreślił, że bardzo sobie ceni „tradycyjne bliskie stosunki z Koreą Północną", ale z powodu napiętej sytuacji w regionie musi podjąć współpracę ze społecznością międzynarodowa, w celu denuklearyzacji Półwyspu Koreańskiego. Ponadto Hu Jintao miał zaznaczyć, że „,atomowa Korea Północna byłaby nie do zaakceptowania" (Bayer, Dziak, 2006: 255-256). Co więcej, w zamian za przyjęcie ustępstw w sprawach nuklearnych zadeklarował, że uzyska od Stanów Zjednoczonych zobowiązania do nieagresji wobec Korei Północnej, wraz z gwarancjami chińskimi i rosyjskimi. Przedstawiciele Chińskiej Republiki Ludowej podkreślili również, że w przypadku wojny spowodowanej północnokoreańską prowokacją zaangażowanie Chińczyków jest nie do przyjęcia, a Układ o przyjaźni, wspótpracy i wzajemnej pomocy zawarty w $1961 \mathrm{r}$. nie będzie obowiązywał. Według źródeł chińskich owe zobowiązania, gwarancje i ostrzeżenia przyczyniły się ostatecznie do podjęcia decyzji przez Kim Dzong Ila o przystąpieniu Korei Północnej do rozmów sześciostronnych (Bayer, Dziak, 2006: 256).

${ }^{4}$ W opublikowanym wówczas oświadczeniu Korea Północna uznała wizytę Jamesa Kelly’ego za „kamień milowy w stosunkach amerykańsko-północnokoreańskich”, jednakże USA zalecały ostrożność w formułowaniu takich opinii. 
Stanowiska państw uczestniczących w pierwszej rundzie rozmów sześciostronnych

\begin{tabular}{|c|c|c|c|}
\hline Państwo & Priorytety polityczne & Proponowane rozwiązanie & Argument przetargowy \\
\hline $\begin{array}{l}\text { Korea } \\
\text { Południowa }\end{array}$ & $\begin{array}{l}\text { Negocjacje jako podstawa poko- } \\
\text { jowego rozwiązania spornych } \\
\text { spraw oraz rozwoju Półwyspu } \\
\text { Koreańskiego }\end{array}$ & $\begin{array}{l}\text { Etapowe, w kierunku całościo- } \\
\text { wego }\end{array}$ & $\begin{array}{l}\text { Pomoc gospodarcza dla Korei } \\
\text { Północnej }\end{array}$ \\
\hline $\begin{array}{l}\text { Korea } \\
\text { Północna }\end{array}$ & $\begin{array}{l}\text { Uzyskanie gwarancji dla reżimu } \\
\text { oraz ustanowienie stosunków } \\
\text { dyplomatycznych ze Stanami } \\
\text { Zjednoczonymi i Japonią }\end{array}$ & $\begin{array}{l}\text { Etapowe i całościowe, pod wa- } \\
\text { runkiem uzyskania gwarancji ze } \\
\text { strony Stanów Zjednoczonych }\end{array}$ & $\begin{array}{l}\text { Likwidacja broni atomowej i ar- } \\
\text { senału rakietowego }\end{array}$ \\
\hline $\begin{array}{l}\text { Stany } \\
\text { Zjednoczone }\end{array}$ & $\begin{array}{l}\text { Całkowita, dająca się skontrolo- } \\
\text { wać i nieodwołalna likwidacja } \\
\text { broni jądrowej }\end{array}$ & $\begin{array}{l}\text { Rozwiązanie całościowe, pod } \\
\text { warunkiem zlikwidowania bro- } \\
\text { ni atomowej przez Koreę Północ- } \\
\text { ną }\end{array}$ & $\begin{array}{l}\text { Gwarancje dla reżimu Korei } \\
\text { Północnej }\end{array}$ \\
\hline Chiny & $\begin{array}{l}\text { Nierozprzestrzenianie broni } \\
\text { masowego rażenia i zachowanie } \\
\text { wpływów na Półwyspie Kore- } \\
\text { ańskim }\end{array}$ & $\begin{array}{l}\text { Prowadzenie aktywnej mediacji } \\
\text { między Koreą Północną a Sta- } \\
\text { nami Zjednoczonymi oraz } \\
\text { działanie na rzecz zapewnienia } \\
\text { gwarancji dla Korei Północnej }\end{array}$ & $\begin{array}{l}\text { Udzielenie pomocy gospodar- } \\
\text { czej }\end{array}$ \\
\hline Rosja & $\begin{array}{l}\text { Likwidacja północnokoreań- } \\
\text { skiej broni atomowej oraz } \\
\text { działanie na rzecz umacniania } \\
\text { stabilizacji w regionie Azji } \\
\text { Północno-Wschodniej }\end{array}$ & Prowadzenie mediacji & Dyplomacja „buforowa” \\
\hline
\end{tabular}

Źródło: J. Bayer, W. J. Dziak, Korea \& Chiny. Strategia i polityka, Warszawa 2006, s. 265; S. J. Hong, North Korean Nuclear Crisis: Prospects and Policy Directions, „East Asian Review” 2003, No. 15, s. 31.

W ocenie profesora Koh Byung Chula z Uniwersytetu Illinois, ChRL była „największym zwycięzcą" pierwszej rundy rozmów sześciostronnych, ponieważ to właśnie dzięki aktywnej chińskiej mediacji i wysiłkom dyplomatycznym doszło do bezprecedensowego spotkania przedstawicieli obu państw koreańskich i czterech państw najbardziej zainteresowanych w utrzymaniu pokoju i stabilizacji na Półwyspie Koreańskim (Koh, 2003: 11-13; Bayer, Dziak, 2006: 264). Jednakże pomimo uczestnictwa północnokoreańskich przedstawicieli w rozmowach sześciostronnych ukierunkowanych na znalezienie pokojowego rozwiązania kwestii nuklearnej, w lutym 2005 r. Korea Północna po raz pierwszy ogłosiła publicznie, że posiada broń atomową. Spowodowało to nałożenie kolejnych amerykańskich sankcji finansowych i zawieszenie rozmów sześciostronnych (Schell, 2007: 67).

Negocjacje wznowiono we wrześniu i mimo, że długo nie rokowały nadziei, okazały się przełomem, gdyż uczestniczące w nim strony podpisały 19 września Wspólne oświadczenie, w którym jednogłośnie zadeklarowano, iż celem rozmów sześciostronnych jest pokojowa i możliwa do skontrolowania denuklearyzacja Półwyspu Koreańskiego. Ponadto w sześciopunktowym oświadczeniu Korea Północna zobowiązała się do „rezygnacji ze wszelkiej broni jądrowej i obecnych programów atomowych” a także do ponownego członkostwa w Układzie o nierozprzestrzenianiu broni jądrowej oraz w Międzynarodowej Agencji Energii Atomowej. Stany Zjednoczone oświadczyły, że nie posiadają broni atomowej na Półwyspie Koreańskim oraz nie planują ataku lub 
inwazji na Koreę Północną przy zastosowaniu broni jądrowej lub konwencjonalnej. Stwierdzono również, że Wspólna deklaracja o denuklearyzacji Półwyspu Koreańskiego, podpisana przez przedstawicieli obu państw koreańskich 31 grudnia 1991 r. powinna pozostać w mocy przy zastrzeżeniu o prawie Korei Północnej do pokojowego wykorzystywania energii atomowej (Bayer, Dziak, 2006: 276).

Tymczasem po wcześniejszym oświadczeniu o zamiarach wykonania testu z bronią jądrową, 9 października 2006 r. północnokoreańskie władze przeprowadziły pierwszą w historii próbę jądrową. W takich okolicznościach Rada Bezpieczeństwa ONZ przyjęła rezolucję nr 1718 wprowadzającą sankcje gospodarcze, polityczne i zbrojeniowe wobec Korei Północnej. Pomimo obowiązywania sankcji, w lutym 2007 r. w Pekinie odbyła się kolejna runda rozmów sześciostronnych. W wyniku dyplomatycznych negocjacji rząd północnokoreański w zamian za pomoc gospodarczą zobowiązał się zawiesić prace nad programem nuklearnym, zamknać reaktor w głównym ośrodku północnokoreańskiego programu jądrowego Yŏngbyŏn oraz umożliwić kontrolę przedstawicielom Międzynarodowej Agencji Energii Atomowej. W lipcu tego samego roku miała miejsce wizyta inspektorów Agencji w Yŏngbyŏn w celu omówienia planów demontażu instalacji nuklearnych. Realizacja północnokoreańskich zobowiązań nie doszła jednak do skutku z powodu problemów ze współpracą ze strony Korei Północnej ${ }^{5}$.

Rozmowy sześciostronne ostatecznie załamały się 26 sierpnia 2008 r., z powodu wstrzymania demontażu urządzeń jądrowych i groźbą ich ponownego uruchomienia przez władze Korei Północnej. Próba rozwiązania północnokoreańskiego problemu nuklearnego w ramach rozmów sześciostronnych okazała się bezowocna, mimo, że w październiku 2008 r. Departament Stanu USA skreślił Koreę Północną z listy państw wspierających terroryzm.

Po objęciu władzy w 2009 r. amerykański prezydent Barrack Obama zadeklarował wolę kontynuacji rozmów sześciostronnych oraz oświadczył, iż zamierza działać na rzecz rozbrojenia jądrowego na świecie (Kim, 2011: 276-277). Jednakże w 2009 r. sytuacja ponownie stała się napięta na skutek wystrzelenia w kwietniu rakiety Taepodong-2, a 25 maja przeprowadzenia drugiej próby atomowej. Po raz kolejny Rada Bezpieczeństwa ONZ potępiła władze Korei Północnej i uchwaliła rezolucję nr 1874 (North Korea, 2009) oraz rozszerzyła sankcje wobec tego państwa, zapisane w rezolucji nr 1718. Nowa rezolucja umożliwiała innym państwom sprawowanie kontroli nad wszystkimi ładunkami transportowanymi zarówno do jak i z Korei Północnej w przypadku podejrzenia, iż zawierają towary zagrażające bezpieczeństwu międzynarodowemu. Rezolucja nakłaniała również do nieudzielania kredytów i pożyczek przeznaczonych do rozwoju północnokoreańskiego programu nuklearnego i rakietowego.

Pomimo wprowadzonych rezolucji i sankcji władze północnokoreańskie zdecydowały się w lipcu przeprowadzić test rakietowy przy użyciu rakiet średniego zasięgu. Przedstawiciele Stanów Zjednoczonych i Korei Północnej zdecydowali się nawet na rozpoczęcie kolejnych negocjacji, które niebawem zostały po raz kolejny zawieszone na skutek niespodziewanego wystrzelenia pięciu kolejnych północnokoreańskich rakiet.

5 Pomimo, że w lipcu 2007 r. zamknięto ośrodek nuklearny w Yŏngbyŏn, a następnie poddano go wstępnej kontroli przez przedstawicieli Międzynarodowej Agencji Energii Atomowej, to jednak wcześniejsze ustalenia nie zostały zrealizowane. 
W 2010 r. źródła w Waszyngtonie, na które powołuje się agencja Reuters podały informację, iż amerykański fizyk atomowy Siegfried Hecker oświadczył, że podczas pobytu w Korei Północnej widział zakłady posiadające wielkie ilości wirówek służących do wzbogacania uranu. Według jednego z tych źródeł, władze północnokoreańskie poinformowały Heckera, iż w zakładach znajduje się około 2000 działających wirówek. Amerykańska delegacja nie była jednak w stanie zweryfikować podanych informacji. Sytuacja ta wskazywała, iż północnokoreański program atomowy podążał w nowym kierunku (Hecker, 2010) ${ }^{6}$. W związku z ujawnieniem w listopadzie 2010 r. północnokoreańskich prac nad wzbogacaniem uranu w nieznanym dotychczas ośrodku nuklearnym, Stephen Bosworth, specjalny wysłannik USA ds. Korei Północnej, odwiedził Koreę Południową, ChRL i Japonię w celu omówienia z władzami tych krajów problemu atomowego na Półwyspie Koreańskim. Upublicznienie informacji o „nowym” ośrodku nuklearnym było próbą Korei Północnej mającą na celu wymuszenie wznowienia rozmów sześciostronnych, jak i uznania Korei Północnej za mocarstwo atomowe (Analiza, 2011).

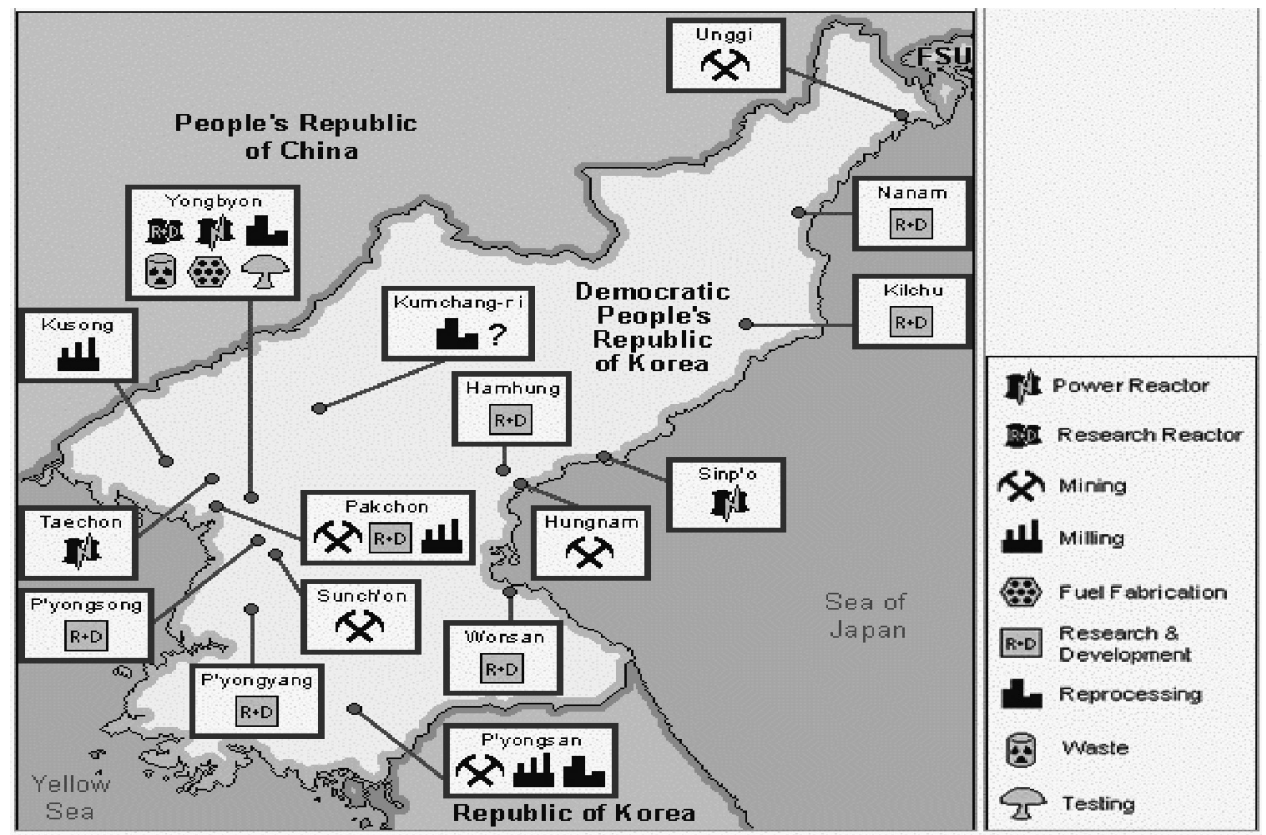

Rys. 1. Północnokoreańskie ośrodki nuklearne

Objaśnienia do rysunku: Yongbyon (reaktor (lekka woda), reaktor gazowo-grafitowy, przetwarzanie materiałów nuklearnych, produkcja paliwa nuklearnego, odpady, testy, poligony doświadczalne); Taechon (reaktor (lekka woda)); Pyongsong, Pyongyang, Wonsan, Kilchu, Nanam, Hamburg (badania rozwojowe); Unggi, Hungnam (przemysł wydobywczy); Pyongsan (przemysł wydobywczy, przetwarzanie materiałów nuklearnych, frezowanie); Pakchon (przemysł wydobywczy, badania rozwojowe, frezowanie); Kusong (frezowanie); Kumchangri (przetwarzanie materiałów nuklearnych).

Źródło: Monterey Institute of International Studies, Center for Nonproliferation Studies, http://fire.pppl.gov/ nk_nuc_fac.html.

${ }^{6}$ Siegfried Hecker, amerykański fizyk atomowy udał się do ośrodka nuklearnego Yŏngbyŏn w Korei Północnej na zaproszenie północnokoreańskich władz. 
Pod względem jakościowym północnokoreański potencjał wojskowy nie dorównuje siłom zbrojnym Korei Południowej i Stanów Zjednoczonych, pomimo posiadania liczebnej przewagi. W opinii specjalistów pewne cechy strukturalne sił zbrojnych Korei Północnej klasyfikują je jako wielce ofensywne. Po pierwsze, wynika to z wielkiej koncentracji artylerii dalekiego zasięgu i rakietowej zlokalizowanej w pobliżu linii zdemilitaryzowanej, która posiada zdolność rażenia celów południowokoreańskich w odległości przekraczającej 50 kilometrów. Po drugie, północnokoreańskie siły zbrojne posiadają znacznie większą liczbę jednostek do działań specjalnych. Po trzecie, znaczącym elementem uzbrojenia północnokoreańskiej armii są rakiety krótszego i dalszego zasięgu (np. SCUD-B - 300 km; SCUD - 500 km; Nodong - 1000 km; Taepodong-2 - 4000-6000 km).

Tabela 2

Struktura i poziom zbrojeń konwencjonalnych na Półwyspie Koreańskim

\begin{tabular}{|c|c|c|c|}
\hline $\begin{array}{c}\text { Struktura i rodzaje } \\
\text { sil zbrojnych }\end{array}$ & Korea Północna & Korea Południowa & Stany Zjednoczone \\
\hline $\begin{array}{l}\text { Liczba żołnierzy } \\
\text { ogółem } \\
\text { rezerwiści }\end{array}$ & $\begin{array}{l}1082000 \\
4700000 \\
\end{array}$ & $\begin{array}{r}686000 \\
4500000 \\
\end{array}$ & $\begin{array}{c}35654 \\
-\end{array}$ \\
\hline Sily lądowe & 950000 & 560000 & 27200 \\
\hline \multicolumn{4}{|l|}{ Liczba żołnierzy } \\
\hline Czołgi & $6500 *$ & 1000 & 116 \\
\hline Czołgi lekkie & 560 & - & - \\
\hline Wozy pancerne & 2500 & 2480 & 111 \\
\hline Artyleria & 10400 & 6474 & 45 \\
\hline Moździerze & 7500 & 6000 & - \\
\hline Rakiety ziemia-ziemia & $64 * *$ & 12 & - \\
\hline Rakiety ziemia-powietrze & 10000 & 1090 & 1 bateria rakiet Patriot \\
\hline Helikoptery & - & 407 & 363 \\
\hline Marynarka wojenna & 46000 & 63000 & 300 \\
\hline \multicolumn{4}{|l|}{ Liczba marynarzy } \\
\hline Łodzie podwodne & 26 & 20 & - \\
\hline Okręty nawodne & 3 & 39 & - \\
\hline Okręty patrolowe & 310 & 84 & - \\
\hline Stawiacze min & 23 & 12 & - \\
\hline Amfibie & 10 & 12 & - \\
\hline Siły powietrzne & 86000 & 63000 & 8300 \\
\hline \multicolumn{4}{|l|}{ Liczba żołnierzy } \\
\hline Samoloty & $\begin{array}{l}3 \text { dywizje bombowców } \\
2 \text { dywizje wsparcia } \\
1 \text { dywizja szkoleniowa }\end{array}$ & $\begin{array}{l}7 \text { dywizji myśliwców } \\
2 \text { dywizje rozpoznawcze } \\
1 \text { dywizja szkoleniowa }\end{array}$ & $\begin{array}{l}4 \text { dywizje myśliwców } \\
1 \text { dywizja ratownictwa } \\
1 \text { dywizja operacji specjal- } \\
\text { nych } \\
1 \text { dywizja rozpoznawcza }\end{array}$ \\
\hline
\end{tabular}

* Czołgi typu: T-55, T-55, T-62, PT-76, PT-85, Ch’ŏnma-ho, P’okp’ung-ho.

** Rakiety: 24 rakiety typu Frog 3 i Frog 7, ok. 30 rakiet krótkiego zasięgu SCUD-C i 10 rakiet dalszego zasięgu Nodong.

Źródło: E. Haliżak, Regionalny kompleks bezpieczeństwa Azji Północno-Wschodniej, „Żurawia Papers” 2004, nr 3, s. 43-44; The Military Balance 2002-2003, International Institute for Strategic Studies, London 2002. 
Jak słusznie podkreśla Edward Haliżak, zakres zbrojeń konwencjonalnych znacząco przekracza potrzeby obronne Korei Północnej. Zagrożenie wynikające z posiadania rakiet przez reżim północnokoreański pochodzi stąd, że mogą one przenosić zarówno ładunki konwencjonalne, jak i broń masowego rażenia (Haliżak, 2004: 45).

Północnokoreański program nuklearny pomimo swoich niewielkich rozmiarów oceniany jest za szczególnie destabilizujący sytuację w regionie Azji Północno-Wschodniej. Półwysep Koreański ciaggle pozostaje miejscem regionalnego zagrożenia bezpieczeństwa, a Korea Północna pomimo podpisanych porozumień ${ }^{7}$ nadal pozostaje nieprzewidywalnym państwem szantażującym społeczność międzynarodową bronią atomową. Ocenia się, że przejęcie władzy w północnokoreańskim państwie przez Kim Dzong Una nie wpłynie na zmianę wojskowego programu jądrowego Korei Północnej. Oznacza to kontynuację polityki nuklearnej Kim Dzong Ila. Ponadto całkowita denuklearyzacja, otwarcie na radykalne reformy wydają się w najbliższym czasie mało realne. Co więcej, północnokoreańskie władze oficjalnie oświadczyły, że nie zamierzają zrezygnować z broni jądrowej do czasu zaprzestania „wrogiej polityki” ze strony Stanów Zjednoczonych, a także dopóki nie zostaną znormalizowane relacje Korei Północnej ze Stanami Zjednoczonymi. Przedstawiciele Korei Północnej są także zainteresowani rozmowami dotyczącymi porozumienia pokojowego z USA (zastępującego układ rozejmowy z 1953 r.) i postulują zniesienie sankcji przed ewentualnym wznowieniem rozmów sześciostronnych (Grinter, 2008: 294-297; Analiza, 2011).

Władze Korei Północnej niejednokrotnie deklarowały chęć powrotu do negocjacji sześciostronnych, proponując ,rozbrojenie za pomoc gospodarczą”. Jednakże z uwagi na przeprowadzone próby jądrowe, zarówno Korea Południowa, jak i Stany Zjednoczone przyjmują z dystansem północnokoreańskie deklaracje o denuklearyzacji (Naukowiec ujawnia, 2011; Albright, 2005: 451) ${ }^{8}$. Należy również podkreślić, że północnokoreańskie władze nie przejawiają zainteresowania reformą swojego systemu politycznego, gdyż ich celem jest przetrwanie reżimu. Publiczne oświadczenia Korei Północnej o otwartości na dialog, negocjacje i ustępstwa niegwarantujące przyjętych wcześniej zobowiązań pokazują prowokacyjne oblicze północnokoreańskiej polityki jądrowej. Okazuje się, że jedno z najbiedniejszych państw świata z powodu broni atomowej ciaggle pozostaje wyzwaniem dla społeczności międzynarodowej.

\section{Bibliografia}

Albright M. (2005), Pani sekretarz stanu, Warszawa.

Bayer J., Dziak W. J. (2006), Korea \& Chiny. Strategia i polityka, Warszawa.

7 Korea Północna naruszyła takie porozumienia, jak: Układ o nierozprzestrzenianiu broni jądrowej, Umowe z Międzynarodowa Agencja Energii Atomowej (dotyczącą kontroli urządzeń jądrowych), Genewskie porozumienie amerykańsko-pótnocnokoreańskie w kwestii nuklearnej (tzw. Porozumienie ramowe) oraz Wspólnq deklarację o denuklearyzacji Pólwyspu Koreańskiego.

8 W dniach 23-25 października 2000 r. doszło do historycznego spotkania Madeleine Albright amerykańskiej sekretarz stanu w rządzie Billa Clintona z przywódcą Korei Północnej Kim Dzong Ilem, który zobowiązał się wówczas do wstrzymania prób z rakietami dalekiego zasięgu. 
Buzo A. (1999), The Guerilla Dynasty. Politics and Leadership in North Korea, London-New York.

Cha V. D. (2012), The Impossible State: North Korea, Past and Future, New York.

Cha V. D., Kang D. C. (2003), Nuclear Korea: A Debate on Engagement Strategies, New York.

Fischer D. (1997), History of the International Atomic Energy Agency, Vienna.

Fisher S. (2006), Axis of Evil World Tour: An American's Travels in Iran, Iraq and North Korea, New York.

Flint C. (2011), Introduction to Geopolitics, New York.

Levin N. D., Han Y. S (2002), Sunshine in Korea. The South Korean Debate over Policies Toward North Korea, Santa Monica CA.

Oberdorfer D. (2001), The Two Koreas: A Contemporary History, New York.

Schell J. (2007), The Seventh Decade: The New Shape of Nuclear Danger, New York.

The Military Balance 2002-2003 (2002), International Institute for Strategic Studies, London.

Wit J. S., Poneman D., Gallucci R. L. (2004), Going Critical: The First North Korea Nuclear Crisis, Washington D.C.

Grinter L. E. (2008), The Six-Party Talks and the Future Denuclearization and Rehabilitation of North Korea, „Pacific Focus”, Vol. 23, No. 3.

Haliżak E. (2004), Regionalny kompleks bezpieczeństwa Azji Pótnocno-Wschodniej, „Żurawia Papers", zeszyt 3.

Hong S. J. (2003), North Korean Nuclear Crisis: Prospects and Policy Directions, „East Asian Review", Vol. 15, No. 3.

Kim J. H. (2011), Toward a Comprehensive Understanding of North Korea's Nuclear Conundrum: The Six Parties in Complex Interdependence from 2002 to 2008, „Asian Politics \& Policy”, Vol. 3, No. 2.

Koh B. C. (2003), Six Party Talks: The Last Chance for Peace?, „East Asian Review”, Vol. 15, No. 4.

Perry W. J. (2006), Proliferation on the Peninsula: Five North Korean Nuclear Crises, „The Annals of the American Academy of Political and Social Science", Vol. 78, No. 607.

Twomey Ch. (2008), Explaining Chinese Foreign Policy toward North Korea: Navigating between the Scylla and Charybdis of Proliferation and Instability, ,Journal of Contemporary China”, Vol. 17, No. 56.

Analiza nt. obecnej sytuacji na Pótwyspie Koreańskim i uwarunkowań międzynarodowych konfliktu (2011), Biuro Bezpieczeństwa Narodowego, Departament Analiz Strategicznych, Warszawa.

Hecker S. (2010), A Return Trip to North Korea's Yongbyon Nuclear Complex, Siegfried Center for International Security and Cooperation, Stanford University, http://iis-db.stanford.edu/pubs/ 23035/HeckerYongbyon.pdf, 10.06.2013.

Heo U. (2006), North Korea Nuclear Test: Cause, Implications and Prospects, Praeger Security International, http://psi.praeger.com/commentary/commentary.aspx, 10.06.2013.

Naukowiec ujawnia nuklearne zbrojenia Korei Pótnocnej (2010), „Gazeta Wyborcza”, 21.11.2010, http://wyborcza.pl/1,76842,8692386,Naukowiec_ujawnia_nuklearne_zbrojenia_Korei_Polnocnej.html, 10.06.2013.

North Korea Sanctions: Resolution 1718 Versus Resolution 1874 (2009), U.S. Department of State, Diplomacy in Action, http://www.state.gov/r/pa/prs/ps/2009/06a/ 124709.htm, 10.06.2013.

Wystannik USA w Korei Pólnocnej (2002), „Gazeta Wyborcza”, http://wyborcza.pl/,75248,1047376.html, 10.06.2013. 


\title{
STRESZCZENIE
}

Rozmowy sześciostronne prowadzone między Koreą Północną, Koreą Południową, Stanami Zjednoczonymi, ChRL, Rosją i Japonią na temat denuklearyzacji Półwyspu Koreańskiego rozpoczęły się pod koniec sierpnia 2003 r. Ich celem jest przekonanie Pjongjangu do rezygnacji z programu nuklearnego w zamian za międzynarodową pomoc gospodarczą. Pomimo wielu deklaracji Korea Północna nie zrezygnowała ze swoich atomowych aspiracji i nie zamknęła reaktora w głównym ośrodku północnokoreańskiego programu jądrowego w Yŏngbyŏn. Publiczne oświadczenie Korei Północnej o posiadaniu broni jądrowej w 2002 r., a następnie przeprowadzenie prób atomowych w 2006 r. i 2009 r. pokazało, że szantaż nuklearny jest metodą prowadzenia polityki umożliwiającą funkcjonowanie północnokoreańskiego reżimu.

\section{THE SIX-PARTY TALKS - A DIPLOMATIC CHALLENGE TO THE PROBLEM OF DENUCLEARIZATION OF THE KOREAN PENINSULA}

\begin{abstract}
The Six-Party Talks, held between North Korea, South Korea, the United States, China, Russia and Japan on the denuclearization of the Korean Peninsula, began in late August 2003. The goal of the talks was to persuade P'yŏngyang to abandon its nuclear program in exchange for international economic assistance. Despite North Korea's many declarations of intent to do so, North Korea did not give up its nuclear aspirations and the government of P'yŏngyang restarted operations at Yŏngbyŏn. Public statements by North Korea that it possessed nuclear weapons since 2002 were followed by nuclear tests in 2006 and 2009, which has demonstrated that nuclear blackmail is a method of foreign policy being carried out by the North Korean regime.
\end{abstract}


